\title{
IMMUNITY BOOSTERS AT ALIMENTARY AND PHYSICAL LEVELS IN RELEVANCE TO COVID-19
}

\section{Seema Raj, Nidhi Bansal, Arun Kaushik, Manish Kumar, Chhavi Kaushik, Aarti Gangadhar Shinde, Dinesh Kumar, Hunny, Anjali Chauhan \\ E-Mail Id: seema.raj@krmangalam.edu.in}

K. R. Mangalam University, Sohna Road, Gurugram, Haryana, India

\begin{abstract}
Nature has its own power to cure each and every living being, we the humans are continuously not acknowledging these natural medicines and therapies which are already mentioned in our culture or olden times. The most fundamental definition of immunity is the ability of the organism to resist the attack of microorganisms and harmful substances. Many herbs, fruits, vegetables, dry fruits, spices, Vitamins, Minerals etc. may act as immunity booster for humans. The intensity of "Yoga", to cure and avoid diseases or as immunity boosting capacity is a well known fact. Considering the facts of COVID 19, this review is an amalgamation of alimentary and physical components which helps to boost the immunity in humans.
\end{abstract}

Keywords: immunity, booster, herbs, fruits, spices, Yoga.

\section{INTRODUCTION}

Immune system is always associated with white blood corpuscles present in the blood. Such cells are efficient to deal with strange organism and have the ability to destroy the same. By this feedback blood plasma generates antibodies in blood, which attack on particular organism in future. This process is known as natural immunity. This allows the human body to remember the antibodies produced and also prepares the body for a new infection [1].

Year 2019 to 2021 will always remembered by the generations due to pandemic of COVID-19. COVID-19 or Corona virus is a group of viruses which belong to the family of Coronaviridae. These groups cause a lot of illnesses such as common cold and can also evolve into deadlier forms such as SARS (Severe Acute Respiratory Syndrome) and MERS (Middle East respiratory syndrome) viruses. It is also important to know the composition of these viruses; they consist of enveloped particles called Virions. The outer ring of these virions is made up of such capsules; each capsule also called the 'nucleocapsid' contains the viral nucleic acids. A collection of these viruses forms a group also known as the genome which consists of a single strand of positive infectious RNA (ribonucleic acid) [2].

Basically, the corona virus is a respiratory virus, which means that it spreads through respiratory droplets i.e., cough or sneeze droplets. The corona virus is a shell which consists of genetic material and proteins. In order to replicate, it requires a living host. Now according to the Centre for Disease control and Prevention, this virus also spreads majorly through person-to-person contact. For example, imagine you are seated in a bus or in a meeting next to someone who is infected with SARS-CoV-2 (SARS COVID-19 virus). Perhaps when you meet that someone, they may have touched their nose or mouth and you shake their hand which is infected. This causes the transmission of some particles of the virus onto your hand. Remember that the virus can also be present on their skin or cloths and can also be transmitted upon touch. If you touch your own nose or mouth, then this will the virus an entry into your own body, thus, you will become an infected person. It is important to know that even if you do not show any symptoms must maintain distance from non-infected people [3]. It is reported that the elder people are more targeted by this virus because of less immunity [4].

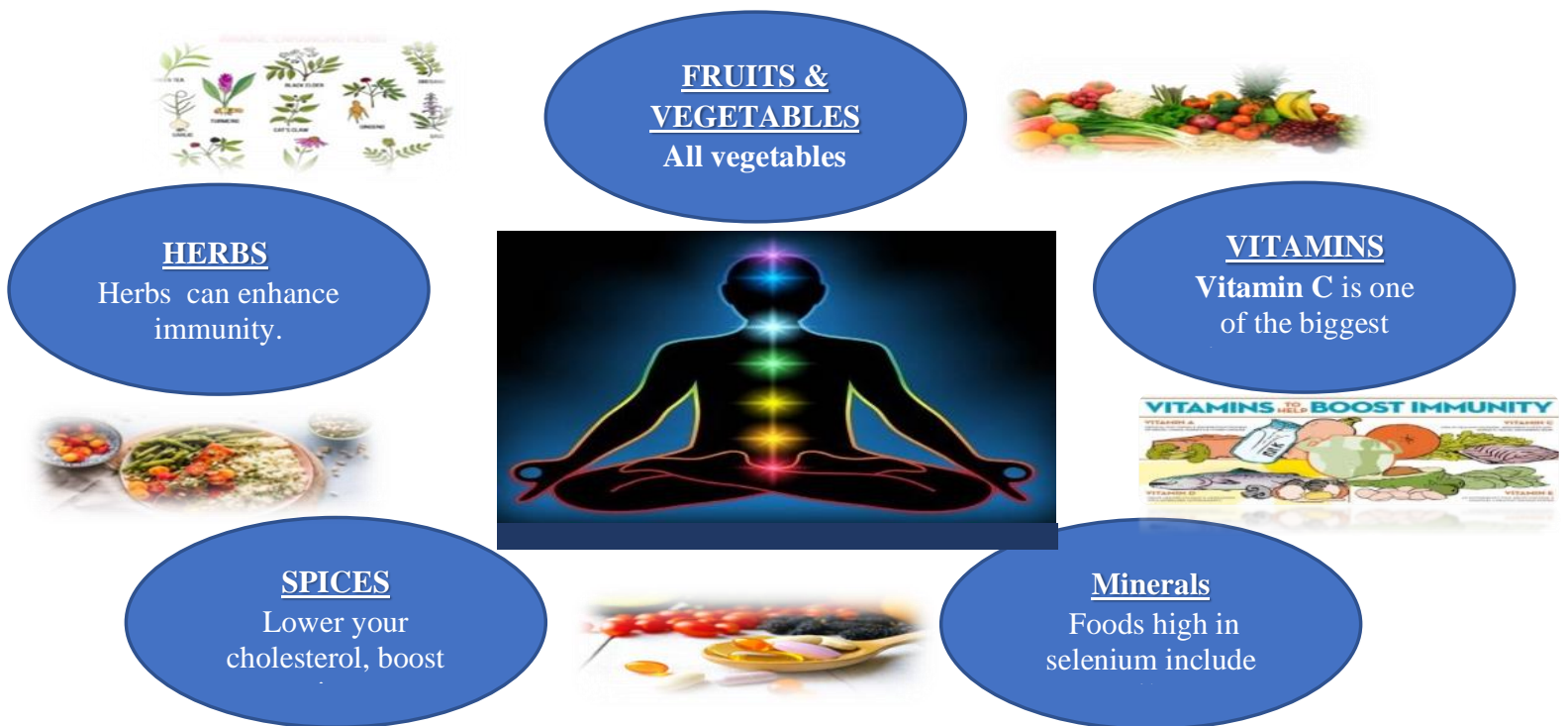

Fig. 1.1 Nutritional and physical factors as immunity booster in humans

DOI Number: https://doi.org/10.30780/specialissue-ICAASET021/021 
According to the research aging is also a factor related to immunity proper nutrition is always required at each step of life. Nutrient plays a vital role to develop immunity as it affects the metabolism. One nutrient can alter the metabolism of other nutrient [5]. It is well-known that deprived people with malnutrition status have higher risk of infection [6-8].

Apart from biological processes, variety of nutritional components may be used as immunity boosters in humans, which inhibits the infections through viruses. It is recommended to follow a healthy and nutritious diet to boost one's immunity. As per researches it was reported that variety of fruits, vegetables, dry fruits, herbs, spices, Vitamins and some elements etc. help to boost immunity of human being [9-10]. Figure 1 reflects the role of immunity boosters to provide a healthy body.Immune boosting system gives a frame to destruct viruses. According to studies people should work on their immunity. The immune system relates to inflammatory functions, modulating cell-mediated immunity, altering and promoting the antigen-presenting cellular functions between the innate and adaptive immune responses. Moderate exercise, good sleep, stress less life, having nutrient rich food and keep hydrating the body, are always develop immunity in a natural way [11].

This review is a study of different immunity boosters (Figure 1) which can heal the body or prevent the body from any disease.

\section{FRUITS AND VEGETABLES AS IMMUNITY BOOSTER}

Fruits and vegetable are those raw immunity boosters which we can arrange from anywhere. These are very effective nutrition [12]. It was reported that to eat fresh vegetables and salads at every meal, as well as fresh fruits to increase the efficiency of the immune system, especially for the patient of the digestive system and to clean the body [13]. Cabbage, broccoli, cauliflower, beetroot, carrots, pepper, radish, watercress, parsley, celery, red onion, garlic, pumpkin, eggplant, tomatoes, green beans, potatoes, spinach, artichoke, turnip [14-15]. Among fruits Pomegranate, grapefruit, orange, strawberry, avocado, bananas, grapes, apples, pears, melons, berries, cantaloupe, cherries, kiwi, persimmons, pineapples, apricots, lemons, peaches, dates [16-18].

If we consider juices then Beet juice, celery juice, fresh cabbage juice, asparagus juice, black grape juice, carrot juice, fresh apple juice, fresh lemon juice, orange juice, pineapple juice, pomegranate juice, cranberry juice, raspberry juice, apricot juice, peach juice, pear juice, strawberry juice, cucumber with lemon juice and grapefruit with lemon juice [19-20]. Juices extracted from the organic wheat plant and small organic barley leaf extract, organic oats grasses extract, spirulina, chlorella, organic green dandelion, green broccoli, organic spinach, organic kale, organic parsley, organic cauliflower, seakelp, sea pulse, marine Green Algae, and Marine Vegetables [21-22]. Perhaps the most important elements that maintain our immune system is a healthy balanced diet, which contains all the nutrients of proteins, carbohydrates, fats, vitamins and minerals in a balanced proportions with the adoption of healthy eating habits, such as the increasing of eating vegetables and fresh fruits of all kinds because they contain many useful nutrients [23-24]. As per the researches flavanoids are present in fruits and vegetables which enhance immune system specially in older people, who are more prone to any infection [25].

Fruit and vegetables contain nutrients as antioxidants, Vitamins, anti-inflammatory and many other components which help to maintain immune system [26-27]. In a randomized controlled trail test specific supplements used, which recorded that such supplements increased natural killer cell (NKC) cytotoxicity and lymphocyte proliferation [28-30].

Maturing has been aligned with physiologic, social, and monetary changes that can prompt an undermined healthful status [31-32], and more seasoned populaces have low foods grown from the ground admissions [3334]. Maturing is additionally connected with liberation of the invulnerable framework [35], and more seasoned individuals are at high danger of disease [36], which will likewise adversely affect dietary status. An expansion in foods grown from the ground admission may possibly profit more established populaces in view of their at first low admission of FVs and their adjusted insusceptible status. A thorough appraisal of the impacts of diet on insusceptible framework status and capacity is methodologically unpredictable, and both the counter acting agent reaction to immunization, which addresses a practical trial of the safe framework, by implication testing inborn and versatile invulnerability, and NKC cytotoxicity have been suggested [37].

As instances of COVID ceaselessly expanding, taking day by day security like washing your hands, social removing, practicing and getting sufficient rest is critical to bringing down hazard of contamination. However, keeping a sound and adjusted eating routine to help support your invulnerable framework may likewise give you support. Note that no exploration has been done on food varieties that help battle against COVID-19 explicitly. Nonetheless, past investigations have discovered that eating certain food varieties can improve your wellbeing and reinforce your body's capacity to battle other intrusive infections. Following are some significant vegetables and organic products [38-39], which goes about as invulnerability supporters:

\subsection{Red bell peppers}

Red ringer peppers rule with regards to leafy foods high in nutrient C. According to U.S. Branch of Agriculture, one cup of slashed red ringer peppers contains of nutrient $C$. which is around twice than the orange.

A recent report distributed in the National Institutes of Health found that nutrient $\mathrm{C}$ adds to safe guard by supporting an assortment of cell works and can bring down the danger of respiratory contaminations. It can likewise help the development and fix of tissues in your body. "Every day admission of nutrient $\mathrm{C}$ is fundamental for acceptable wellbeing on the grounds that our bodies don't create it normally," Dr. Seema Sarin, an inside medication doctor at EHE Health, revealed to CNBC Make It.

\subsection{Broccoli}

DOI Number: https://doi.org/10.30780/specialissue-ICAASET021/021

Paper Id: IJTRS-ICAASET2021-021

pg. 120

$$
\text { @2017, IJTRS All Right Reserved, www.ijtrs.com }
$$


Broccoli is likewise plentiful in nutrient C. Simply a large portion of a cup contains $43 \%$ of your day by day worth of nutrient C, as indicated by the National Institute of Health. Broccoli is loaded with phytochemicals and cell reinforcements [40] that help our insusceptible framework. It likewise contains nutrient E, a cell reinforcement that can assist battle with offing microbes and infections.

\subsection{Strawberries}

Strawberries contain nutrient C. Nutrient $C$ is incredible for reinforcing your insusceptible framework since it can help shield cells from harm brought about by free revolutionaries that we're frequently presented to in the climate.

\subsection{Mushrooms}

While sun openness is the best wellspring of nutrient D, it can likewise be given by certain food varieties, including mushrooms. A 2018 audit of mushrooms as a nutrient D source [41] tracked down that the "daylight nutrient" can help upgrade the assimilation of calcium, which is useful for bone wellbeing, and may likewise secure against certain tumors and respiratory illnesses. Mushrooms are extraordinary as a side dish or hors d'oeuvre.

New vegetables and organic products are unique to some other wellspring of insusceptibility promoters, however dry natural products likewise have their own significance. Dry natural products are continually being an inborn piece of Indian and different foods. These are known as invulnerability supporters [43]. Dried natural products give a wide scope of phytochemicals, like phenolic acids, flavonoids, phytoestrogens, and carotenoids. Dried natural products are incredible wellsprings of carbs and sugars, for example, glucose and fructose [44-45]. Dried organic products are huge for human wellbeing in furnishing extraordinary sustenance with medical advantages. More examination ought to be done to decide the total profiles of dried organic products according to their cancer prevention agent exercises or other bioactivities [46]. Almonds are celebrated for its sound skin benefits, Vitamin E, found in almonds, is another cancer prevention agent [47] that has been appeared to help the safe framework as well as hindering the maturing cycle. It goes about as a better than different nutrients, shielding them from oxidation and, in this manner, permitting them to manage their job. According to consider Pistachio has capacity to diminish oxidative pressure after actual exercise [48]. Pecan is additionally am resistance sponsor. In an examination The Changbai Mountain pecan (Juglans mandshurica Maxim.) utilized, which is a rich wellspring of fundamental amino acids. The impact of three kinds of pecan protein hydrolyzates - egg whites, globin, glutelin was analyzed over mice. When contrasted with the ordinary control mice, those treated with various portions of pecan proteins showed improved resistant records [49]. Cashew nut is additionally in the class to upgrade insusceptibility. According to contemplates, as well as containing high measures of copper, cashews are an extraordinary wellspring of Zinc [50]. Lack of zinc bargains your invulnerable framework working, since this mineral is significant for the improvement of insusceptible framework cells, creation of cancer prevention agent chemicals and action of safe framework controllers. In numerous investigations, boosting zinc consumption has been related with a better invulnerable reaction, implying that cashews could help you fend off your next cold [51].

\section{VITAMINS AS IMMUNITY BOOSTERS}

With the detonation in corona virus cases all over the world, scaring the world into talks of an epidemic. Because COVID-19 comes with cold and flu-like symptoms, Vitamins B, C and D, may be helpful in boosting your immune system and fighting the illness in the same way they can help you get over a cold or flu.

Food supplements provide nutrients to those who have inadequate and in the need of it. It can be vitamins, minerals, amino acids, fatty acids, and other substances in the form of pills, tablet, capsules and also powders added to water [53]. In the European Union, it is regulated as foods and not as drugs. There should be sources of nutrients to it with a nutritional, immunologic and physiological effect and not just only by adding another ingredient. Furthermore, it is also shown that food supplements are entirely used by millions of people around the world to meet their health needs. Likewise, immunity Booster is one of the food supplements for keeping our immune system healthy.

Immunity Booster is a food supplement that helps your body to lift up the health of the immune system. Based on the Academy of Nutrition and Dietetics, there are top five essential nutrients needed to boost and strengthen the immunity of the body, it includes Vitamin B, D, C, E, and Zinc [53]. Moreover, the human immune system is also an interface across which many climate changes sensitive exposures can affect health outcomes [54]. An important determinant of climate change from various illnesses caused by pathogens and parasites in human populations, diarrhea, enteric diseases and certain waterborne diseases as stated by the World Health Organization. Therefore, low immunity is a significant threat to human life's that may lead to death.

Antiviral medications can restrict viruses from replication there is no primary way to get rid of a virus and prevent viral infection besides having a strong and healthy immune system. Immune system can detect the infected cells and dispose them before the virus begins to replicate and escape [55].

\subsection{Vitamin B}

Vitamin B is very necessary to be consumed every day and they are water soluble compounds. B community vitamins are coenzymes in some important metabolic pathways, they are essential to maintain many functions in the body, for proper brain functioning, and for the daily the optimal conversion of food to energy. There are 
eight B vitamins (including B1, B2, B3, B5, B6, B7, B9, B12), and it is essential to get a multivitamin that includes all of them or take an additional B-complex [56].

\subsection{Vitamin C}

By and large, nutrient $\mathrm{C}$ can help you battle a cold quicker or facilitate your chilly indications on the off chance that you were taking it preceding becoming ill. As a cancer prevention agent, nutrient $\mathrm{C}$ can help lessen irritation - and lung aggravation is an extreme side effect of COVID-19, which can prompt respiratory trouble or even demise. So in case you're as yet solid, it doesn't damage to begin taking nutrient $\mathrm{C}$ now [57]. This is a decent procedure, as there has been a lot of proof gathered since a century ago about the remedial advantages of nutrient $\mathrm{C}$. Nutrient $\mathrm{C}$ is associated with a few fundamental cycles like energy digestion and quality record, just as in guideline of hormonal and epigenetic pathways. It has antimicrobial properties, which decrease the danger of diseases, and has immuno-modulatory capacities, especially in high fixations. Nutrient $\mathrm{C}$ has additionally been appeared to have against viral, hostile to contagious and hostile to parasitic impacts. Nutrient $\mathrm{C}$ is watersolvent and effectively killed by the stomach related framework so there is no danger of excess. It is prescribed to take your dosages up sufficiently high to actuate free stool while fighting microorganisms. Studies have shown that as lymphocytes and regular executioner cells of the insusceptible framework take up more nutrient $\mathrm{C}$, they become more harmful against microbes [57]. Vitamin $\mathrm{C}$ is also involved with iron absorption; it is because pathogens compete with vitamin $\mathrm{C}$ for iron resources, as it is essential in aerobic metabolism. If pathogens take too much of your iron, they can starve you of energy by starving your cells of oxygen. They produce excessive amounts of free radicals and acidic by-products which can overwhelm the immune system if there is not enough antioxidant defenses available [58].

\subsection{Vitamin D}

The essential capacity of nutrient $\mathrm{D}$ is to assist your body with keeping up ideal blood levels of calcium and phosphorous, which you can get past openness to the sun's bright beams, or through supplements and the food sources you eat. Getting sufficient nutrient D can likewise shield you from respiratory disease. Nutrient D supplementation fundamentally diminishes the opportunity of respiratory parcel contamination [59]. Nutrient D is fundamental for the resistant framework. At the point when skin is presented to daylight it makes nutrient D [60]. The skin likewise needs cholesterol (from fats), just as magnesium, to work with this cycle.

People who live in arctic regions with weak sunlight have survived well by compensating with foods high in vitamin D - such as fatty fish and offal meats [61]. Fish and seaweeds also contain a good amount of magnesium.

\section{SPICES AS IMMUNITY BOOSTER}

The old Greek doctor, Hippocrates, regularly alluded to as the dad of Western medication, when said, "Let food be thy medication, and medication be thy food," Spices are great in light of the fact that, in contrast to drugs, you don't have to "take" them. All things being equal, you can add them to your number one dishes for a kick of flavor and expanded insusceptibility [62].

\subsection{Ginger}

This flexible flavor is recuperated from the foundation of the plant, and an assortment of noteworthy phytochemicals have been disconnected from ginger and found to have antibacterial, mitigating, fever-diminishing, and torment alleviating properties, Traditional Indian Ayurvedic medication uses ginger root as a stomach related guide for youthful newborn children with colic and for grown-ups with heartburn. Ginger is a characteristic solution for queasiness and regurgitating because of nausea and morning affliction of pregnancy [63].

\subsection{Clove}

The oil from this warm, fragrant zest is endorsed in Germany as an effective pain relieving and germicide. Not exclusively do compounds in this flavor present antibacterial and antifungal advantages they likewise help battle the maturing interaction. The high measures of phenols found in cloves are related with the capacity to obstruct the development of cutting edge glycation final results (AGEs) AGEs are non-working mixtures that are related with many age-related conditions like wrinkling of our skin or waterfalls [64].

\subsection{Turmeric}

Curries and other South Asian and Middle Eastern delights ordinarily incorporate the flavor turmeric. The dynamic fixing in turmeric is curcumin, and logical help including curcumin incorporates against malignant growth and mitigating properties [65].

\subsection{Dark pepper}

Dark pepper is something other than a table zest. It contains calming, cancer prevention agent and antibacterial activities, yet in addition insusceptible framework upgrading benefits. In South India, it isn't phenomenal for some to their day with some dark espresso with a touch of dark pepper powder [66].

\subsection{Cinnamon}

Cinnamon comes from the dried bark of an exotic types of Cinnamomum, an evergreen tree filled in Asia. Its dynamic fixing, cinnamaldehyde, is especially powerful at bringing down hazard factors for pre-diabetes, as it stops spikes in glucose after a dinner [67]. 


\subsection{Apiaceae}

It is also known as ajwain, it is a calming specialist, a stomach related guide and a gentle diuretic. Because of calming properties and the capacity to increment mucosal release, ajwain is a generally excellent invulnerability promoter and assists with combatting a cold, affirms Pasricha. "Ajwain can be handily added to imbuements, tadkas or batters for level or prepared bread. It adds both flavor and crunch." The catalysts in ajwain work with the arrival of gastric juices, in this way improving the stomach related capacities [68].

\section{HERBS AS IMMUNITY BOOSTER}

In light of COVID-19 spices may assume significant part to improve resistance. Various investigations have tracked down that this plant may assist your insusceptible framework with combatting contaminations and infections, which could assist you with recuperating ailment. Following are the couple of instances of spices which goes about as shelter of numerous viral diseases:

\subsection{Tulsi}

Ayurveda framework tulsi is regularly alluded to as an "Solution of Life" for its mending powers and has been known to treat various basic ailments. Tulsi is utilized in treatment of epilepsy, asthma or dyspnea, hiccups, hack, skin and hematological sicknesses, parasitic contaminations, neuralgia, cerebral pain, wounds, and irritation [69] and oral conditions [70]. The roots and stems were additionally generally used to treat mosquito and snake chomps and for intestinal sickness [71].

Present day research has uncovered that tulsi has hostile to bacterial; against viral and hostile to contagious action [72] that incorporates movement against numerous microorganisms answerable for human diseases. Tulsi has likewise been appeared to help protections against infective dangers by upgrading insusceptible reactions in no pushed and focused on creatures [73-78] and solid people [79].

\subsection{Echinacea (Coneflower)}

It is a blooming plant that fills in the U.S. also, Canada, and it's been utilized as medication for quite a long time. A portion of its normal names are the purple coneflower or dark peered toward Susan. All pieces of this plant are utilized to make supplements, fluid concentrates, and teas. Concentrates of Echinacea affect the resistant framework through safeguard against germs. According to investigates it builds the quantity of white platelets, which battle contaminations [80]. It is perhaps the most famous natural prescriptions with an expected $1-4 \%$ of everybody utilizing the spice in a given year. It has been mostly utilized in chemo-preventive and chemotherapy for irresistible infections in both upper and lower respiratory frameworks [81]. It was likewise detailed that Echinacea purpurea (Asteraceae) is an enduring restorative spice with significant safe stimulatory and mitigating properties, particularly the lightening of cold side effects. The plant additionally stood out for scientists to evaluate different parts of its advantageous impacts. For example, against uneasiness, hostile to discouragement, cytotoxicity, and antimutagenicity as incited by the plant have been uncovered in different investigations [82].

\subsection{Andrographis Peniculata (Green chiretta)}

Andrographis Peniculata by and large known as "lord of sharp flavoring," is a herbaceous plant in the family Acanthaceae. In India, A. paniculata is known as "Kalmegh". Concentrates of this plant and angrapholide display pharmacological exercises, for example, those that are immunostimulatory, antiviral and antibacterial. As significant dynamic constituent androgropholide display a wide scope of natural antibiotic,diabetic,antimalarial and heptoprotective [83-84]. In Asian nations, A. paniculata has been broadly utilized for its antipyretic, pain relieving, protozoacidal, antihepatotoxic, against HIV, immunostimulant, anticancer impacts [85]. According to the investigations it was proposed that the normal item andrographolide are available in this spice and summed up different exploratory and clinical pharmacological exercises of andrographolide, like cancer prevention agent, calming, anticancer, antimicrobial and parasitic, hepatoprotective, antihyperglycemic, and antihypoglycemic. Confirmation from clinical investigations proposes that andrographolide lessens HIV manifestations, simple upper respiratory parcel diseases, including sinusitis and the normal cold, and rheumatoid joint pain [86].

\subsection{Rosemary}

The leaves of the spice rosemary are utilized new just as dried in conventional Mediterranean dishes to bestow fragrant smells of evergreen. Rosemary has solid cell reinforcement properties, and examination shows that rosemary extricate has both antibacterial [87]. New rosemary leaves is a common remedial portion for boosting insusceptibility during cold weather months.

\subsection{Garlic}

This amazing culinary spice has a wide cluster of medical advantages going from cardiovascular insurance to resistant incitement. The science of garlic is intricate, with more than 100 unique substances that add to its belongings. The main element is garlic's high grouping of sulfur compounds, which are answerable for both the smell of garlic and its adequacy against microscopic organisms, infections and growths [88].

\subsection{Ashwagandha}

Aswagandha holds the most noticeable spot. It is known as "satvic Kapha Rasayana" herb12 [89]. Ayurveda, the 
traditioal arrangement of medication in India can be followed back to 6000 BC [90]. It likewise effectively invigorates the invulnerable system, increase infections battling white platelets creation [91].

\section{MINERALS AS IMMUNITY BOOSTER}

\subsection{Magnesium}

Another extremely important antioxidant nutrient often overlooked is magnesium. Like vitamin C, our body can't make it and we have to get it from outside. There are over 100 years of magnesium research showing magnesium powerfully supports the immune system. Remember when you took a swim in the ocean with a head-cold, that it cleared up quickly afterwards? That's because sea salts dry up mucus and kill pathogenic bacteria. Ocean water also contains a significant amount of magnesium, the master mineral electrolyte, which strengthens our immune system's lymphocytes and natural killer cells. Magnesium is essential to make ATP (adenosine triphosphate) - our cellular energy currency. No detox nor cell building and repair can take place without energy and magnesium is at the centre of the energy production. A good metabolism is the key to resilience in health.

The haemoglobin of red blood cells requires magnesium to help it take up oxygen from lungs and deliver that oxygen to tissue cells in other parts of the body. Researchers believe this is because, as part of the ATP energy currency, magnesium is vital to membrane integrity of red blood cells. The heme protein (containing iron) in these cells needs to 'attract' oxygen molecules from lung sacs as blood passes by. The oxygen molecules need to pass through the red blood cell (RBC) membrane - to get 'onboard' the train so to speak.

Magnesium is in charge of these cell membrane gateways (protein channels), creating just the right charge for proteins to do their oxygen-transporting job. Proteins do their work via attraction or repulsion, which is dependent on electrical charge. As the RBCs pass via tissue cells that need oxygen, the charge (attraction) goes the other way and oxygen molecules pass from the blood to the tissue cells. All these processes require magnesium for correct electrical charge and switching ability. Magnesium-ATP forms our cellular battery pack system. Thus in magnesium deficiency, where less oxygen gets on board, the system becomes anaerobic and acidic, that is, oxidized and damaged by free radicals [92]. A low magnesium status itself can cause inflammation and over-reaction of the immune system.

\subsection{Iron}

Iron is fundamental for practically living beings. Iron controls number of metabolic cycles [93]. It permits it to interrelate reversibly with different iotas particularly, oxygen, sulfur and nitrogen [94]. The safe reaction of iron is the primary line of guard against irresistible difficulties [95]. Iron chelators repress the movement of phagocyte oxidase and diminish receptive oxygen halfway ward executing of bacterial microorganisms under in vitro and in vivo [96].

\subsection{Zinc}

Zinc known as safe sponsor by expanding the body insusceptibility it capacities as cancer prevention agent. Unmistakably zinc is extremely fundamental for our body and assume a vital part in resistance. It assumes a significant part in enacting T cells [97]. It has been assessed that roughly $10 \%$ of the human genome encode for proteins that could tie zinc [98]. It is likewise detailed that zinc goes about as guard for the resistant capacities [99]. Popping a zinc throat capsule or taking a preposterous virus cure with zinc in it (as a syrup or tablet) abbreviates the length of rhinovirus colds. Zinc likewise helps indications - nasal blockage, nasal seepage, sore throat, and hack—resolve sooner [100].

\subsection{Calcium}

Calcium goes about as a second courier in numerous cell types, including lymphocytes. Low grouping of $\mathrm{Ca} 2+$ particles keeps up by resting lymphocytes. Be that as it may, commitment of antigen receptors actuates calcium convergence from the extracellular space by numerous courses. A main component of $\mathrm{Ca} 2+$ section in lymphocytes is through store-worked calcium (SOC) channels [101].

\subsection{Selenium}

Selenium was viewed as a poisonous component for people and animals for almost 150 years [102]. Selenium is a minor element. Human body needs it in limited quantities. Selenium assists your body with creating exceptional proteins, called cell reinforcement compounds. These assume a significant part in forestalling cell harm. Dietary selenium (Se) is a fundamental micronutrient. It improves different parts of human wellbeing, including ideal insusceptible reactions. Se is worried in directing oxidative pressure and other significant natural cycles in essentially all tissues and cell types, incorporating those associated with versatile safe reactions [103105].

\section{YOGASANA FOR BOOSTING IMMUNITY}

'Yoga' is a Sanskrit expression signifying 'association' or 'conjunction'[106], and the fundamental motivation behind yoga is to unite body, psyche and soul into an amicable entirety. The focal strategies for yoga are actual stances or 'asanas' and development, breathing methods or 'pranayama' and reflection. Yoga remembers direction for solid way of life, dietary patterns, mental demeanor, and Ayurvedic medication is likewise essential for the Yogic way to wellbeing and equilibrium.

Yoga is a comprehensive practice that fortifies our actual body, just as the minute frameworks that are not apparent to the eye. Thus, the body's normal protection systems additionally improve. A illness free body can be 
handily accomplished by embracing a sound way of life, including eating natural, entire food varieties, keeping a normal yoga and reflection work on, getting a lot of rest, and limiting stressors. Ayurveda, yoga, and contemplation are the keys to accomplishing our maximum capacity. It is prudent to procure the invulnerable boosting aftereffects of yoga, make certain to keep an everyday practice. In the western world Yoga is chiefly utilized as a sporting practice, it is progressively acquiring consideration as a clinical mediation. Indeed, yoga didn't basically advance as an arrangement of actual activities, yet in addition goes about as a mending framework. This mending framework depends on the hypothesis that an individual is an interesting, all encompassing, and interconnected substance; that yoga can enable an individual to get dynamic in their selfrecuperating; and that an individual's perspective is key to this mending cycle [107]. Yoga might be executed as an integral mediation for populaces in danger or previously experiencing infections with a provocative segment. Past this, yoga practice may apply further useful impacts by upgrading cell-interceded and mucosal insusceptibility [108].

As on January 30, 2020, the World Health Organization additionally pronounced the COVID-19 flare-up a worldwide wellbeing crisis since it could spread to nations that are not readied. Moreover, to forestall the spread of the new and dangerous infection, all urban areas in China presently have closed down most open spots and offices, including parks, leaving numerous individuals with no spot to work out. Accordingly, individuals may contemplate whether one should practice at all during the flare-up and assuming this is the case, how?

It was recommended that even a solitary exercise meeting can be gainful, however ordinary exercise gives a lot greater advantage. Sub-atomic and cell occasions occur inside brief timeframe range following the start of an activity time of active work. In this way, there is such a lot of work right currently looking at sitting time and how frequently actual work ought to be sprinkled with dormancy to advance wellbeing. The set of experiences says that activity advances a battle or flight pressure reaction that activates insusceptible cells to prepare for looming irresistible issues joined by active work [109].

\subsection{IMPACT OF YOGASANAS, PRANAYAMAS AND MEDITATION ON PHYSIOLOGY}

At the hour of yoga practice the cells of pancreas revive which uses digestion of glucose through enzymatic interaction [111-112]. Muscle unwinding improves blood supply to muscles [113]. Lipid levels in blood improve because of which influences the digestion of lipoprotein and subsequently increment take-up of fatty oils by fat tissues [114-115]. Pranayama, extends the lung tissue creating inhibitory signs from activity of gradually adjusting receptors and hyperpolarising flows. These inhibitory signs coming from cardiorespiratory district including "vagi" are accepted to synchronize neural components in the mind prompting improve sensory system [116]. In an examination on contemplation, scientists discovered essentially bigger dark matter volumes in meditators in the privilege orbito-cerebrum, right thalamus and left second rate transient gyrus [117]. Another examination led in Germany on Buddhist priests and nuns with 5 years preparing in reflection rehearses exhibited that rehearsing contemplation sped up consideration, expanded the profundity of data preparing and diminishing reaction delay [118].

\subsection{Impact of Yoga Practices Immunity}

An examination detailed that when a gathering performs yoga rehearses for 12 weeks, their phone insusceptibility expanded as for stress as contrasted and control [119]. In another examination, Yoga practice upgraded body resistance in aspiratory tuberculosis patients potentiated [120]. A portion of the yoga sadhanas or rehearses that are generally polished incorporate [121-130] to upgrade the resistance. In different terms Asanas, yama and niyama, pranayama, dhyana or contemplation, Mudras and Bandhas, Samadhi, Dharana, Pratyahara, Shar-karmas are purging ceremonies. These structure the pre-essentials for the act of yoga. Asanas assist the human body with adjusting the condition of steadiness of psyche. It includes the selection of the basic psychoactual examples, and it gets competent for a person of keeping a body act up to a specific time span. In this manner a portion of the asanas, breathing methods and the integrity of Ayurveda assume their part to keep you quiet, give you sound rest and fortify the body's insusceptible framework. Keeping a solid resistant framework and low degrees of stress become fundamental variables. Ayurvedic professionals and different specialists suggest some accommodating tips in such manner to stay solid. Contorting and twisting your body while doing stances reinforces the lymphatic framework.

\section{CONCLUSION AND FUTURE SCOPE}

After studying all immunity boosters at alimentary and physical levels in relevance to COVID-19, we can conclude that intake of regular nutrition in the form of fruits, vegetables, dry fruits, herbs, spices, minerals, Vitamins etc. and doing regular Yoga may increase immunity level in human beings. More clinical trials are required to establish such components in regular use may be taken into the consideration as future perspectives.

\section{ACKNOWLEDGEMENT}

We would like to acknowledge K. R. Mangalam University, Gurugram, Haryana, India for providing such platform for this study at the time of COVID-19 pandemic lockdown period.

\section{REFERENCES}

[1] Retrieved from https://www.dw.com/en/the-immune-systems-fight-against-the-coronavirus/a-53048894

[2] Retrieved from https://www.who.int/health-topics/coronavirus\#tab=tab_1 
[3] Retrieved form https://www.healthline.com/health/coronavirus-transmission\#from-person-to-person

[4] Zhavoronkov, A.: Geroprotective and senoremediative strategies to reduce the co morbidity, infection rates, severity, and lethality in gerophilic and gerolavic infections. Aging (Albany NY) 12 (2020)1-19

[5] Alam I.: The immune-nutrition interplay in aging - facts and controversies, Aging Dis.15 (2019) 25-33

[6] Katona, P., Katona-Apte, J.: The interaction between nutrition and infection. Clinical Infectious Diseases 46(10): (2008)1582-8

[7] Norman K., Pichard C., Lochs H., Pirlich M.: Prognostic impact of disease-related malnutrition. Clinical Nutrition 27(1) (2008) 5-15

[8] Schaible, U.E., Kaufmann, S.: Malnutrition and Infection: Mechanisms and Global Impacts. Plos Medicine 4(5) (2007)115.

[9] Retrievedfromhttps://www.thehindubusinessline.com/news/science/ayurveda-helps-boost-immunityagainst-covid-19-experts/article31262435.ece\#

[10] Retrieved from https://www.medicinenet.com/script/main/art.asp?articlekey=229772

[11] Sarfraz, I., Rasul, A., Hussain, G., Adem, S., Ali, M.: Natural Immune boosters as first-line armours to combat viral infection-COVID19: Myth or Science? (2020)

[12] Haider A., Sarmad G., Hassan H.: The Effect of Nutrition on Immune System Review Paper. Food Science and Quality Management 50 (2019). DOI: 10.7176/FSQM/90-06

[13] Dhandevi, P. E. M. \& Jeewon, R.: Fruit and vegetable intake: benefits and progress of nutrition education interventions-narrative", review article. Iranian journal of public health 44(10) (2015) 1309

[14] Balch, P. A.: Prescription for dietary wellness. Penguin (2003)

[15] Donsbach, K.W.: Donsbach's Guide to Good Health - Long. Shadow Book (1985)

[16] Sinha N., Sidhu J., Barta J., Wu J. \& Cano M. P.: Handbook of fruits and fruit processing. John Wiley \& Sons (2012)

[17] Kushi L., Doyle C., McCullough M., Rock C. L., Demark Wahnefried, W., Bandera, E. V. \& American Cancer Society 2010 Nutrition and Physical Activity Guidelines Advisory Committee: American Cancer Society Guidelines on nutrition and physical activity for cancer prevention: reducing the risk of cancer with healthy food choices and physical activity.CA: a Cancer Journal for Clinicians 62(1) (2012) 30-67

[18] Calder, P. C.: Feeding the immune system. Proceedings of the Nutrition Society 72(3) (2013) 299-309

[19] Steinmetz, K. A., Potter, J. D.: Vegetables, fruit, and cancer prevention: a review. Journal of the American dietetic association 96(10) (1996) 1027-1039

[20] Jacobson, M. F., Lefferts, L. Y., Garland, A. W.: Safe food: Eating wisely in a risky world. Living Planet Press (1991)

[21] Wardlaw, G. M. \& Kessel, M. W., (2002), "Perspectives in Nutrition," 5th Edition, McGraw-Hill Education, New York.

[22] David, A., Gail, D. \& Adrianne, B. (2004), "Diet and human immune function", New Jersy: Humane Press Inc.

[23] Munkyong, P., Simin, M. \& Dayong, Wu (2012), "The Role of Nutrition in Enhancing Immunity in Aging”, Aging and Disease. 3 (1): 91-129.

[24] Hodkinson, C. F., Kelly, M., Alexander, H. D., Bradbury, I., Robson, P. J., Bonham, M. P. \& Wallace, J. M.

[25] Gibson, A., Edgar, J. D., Neville, C. E., Gilchrist, S. E. C. M., McKinley, M. C., Patterson, C. C., Young, I. S., Woodside, J. V.: Effect of fruit and vegetable consumption on immune function in older people: a randomized controlled trial. Am J Clin Nutr. 96(6) (2012)1429-36

[26] Lampe, J.W.: Health effects of vegetables and fruit: assessing mechanisms of action in human experimental studies. Am J Clin Nutr. 70 (1999) 475S-90S

[27] Webb, A.L., Villamor, E.: Effects of antioxidant and non-antioxidant vitamin supplementation on immune function. Nutr Rev

a. $65(5)(2007) 181-217$

[28] Bub, A., Watzl, B., Blockhaus, M., Briviba, K., Liegibel, U., Muller, H., Rechkemmer, G.: Fruit juice consumption modulates oxidative stress, immune status and DNA damage. Nutr Biochem 14 (2003) 90-8

[29] Watzl, B., Bub, A., Briviba, K., Rechkemmer, G.: Supplementation of a low-carotenoid diet with tomato or carrot juice modulates immune function in healthy men. Ann Nutr Metab. 47(2003) 255-61

[30] Watzl, B., Bub, A., Brandstetter, B.R., Rechkemmer, G.: Modulation of human T-lymphocyte functions by the consumption of carotenoid-rich vegetables. Br J Nutr. 82 (1999) 383-9

[31] Finch, S., Doyle, W., Lowe, C., Bates, C.J., Prentice, A., Smither, G., Clarke, P.C.: National Diet and Nutrition Survey: people aged 65 years and over. Nutrition \& Food Science 98 (3) (1998) 133-134

[32] Meydani, M., Nutrition interventions in aging and age-associated disease. Ann N Y Acad Sci. 61 (2002) 165-71

[33] Appleton, K.M., McGill, R., Woodside, J.V.: Fruit and vegetable consumption in older people in Northern Ireland: levels and patterns. Br J Nutr. 102 (2009) 949-53

[34] Wakimoto, P., Block, G.: Dietary intake, dietary patterns, and changes with age: an epidemiological perspective. J Gerontol A Biol Sci Med Sci. 56 (2001) 65-80

[35] Dorshkind, K., Montecino-Rodriguez, E., Signer, R.: The ageing immune system: is it ever too old to become young again? Nat Rev Immunol. 9 (2009) 57-62 
ICAASET-2021, 20-21 May, 2021, K.R. Mangalam University, Gurugram

International Journal of Technical Research \& Science (Special Issue) ISSN No.:2454-2024 (online)

[36] Gariballa, S.: Vitamin and mineral supplements for preventing infections in older people. BMJ. 331 (2005) 304-5

[37] Albers, R., Antoine, J.M., Bourdet-Sicard, R., Calder, P.C., Gleeson, M., Lesourd, B., Samartin, S., Sanderson, I.R., Van Loo, J., Vas Dias, F.W.: Markers to measure immunomodulation in human nutrition intervention studies. 94 (2005) 452-81

[38] Retrieved from https://www.cnbc.com/2020/04/03/stock-up-on-9-healthy-foods-to-boost-immunesystem-during-coronavirus-doctor-dietitian.html

[39] Retrieved from health/food-nutrition/foods-that-boost-the-immune-system\#shellfish

[40] Hwang, J. H., Lim, S. B. Antioxidant and anticancer activities of broccoli by-products from different cultivars and maturity stages at harvest. Preventive nutrition and food science 20(1) (2015) 8-14

[41] Cardwell, G., Bornman, J. F., James, A. P., Black, L. J.: A Review of Mushrooms as a Potential Source of Dietary Vitamin D. Nutrients10(10) (2018)1498

[42] Ko, S. H., Park, J. H., Kim, S. Y., Lee, S. W., Chun, S. S., Park, E.: Antioxidant Effects of Spinach (Spinacia oleracea L.) Supplementation in Hyperlipidemic Rats. Preventive nutrition and food science 19(1) (2014)19-26

[43] Puri, A., Sahai, R., Singh, K., Saxena, R., Tandon, J., Saxena, K.: Immunostimulant activity of dry fruits and plant materials used in Indian traditional medical system for mothers after child birth and invalids. Journal of Ethnopharmacology 7(1) (2001) 89-92

[44] Alasalvar, C., Shahidi, F.: Composition, phytochemicals and beneficial health effects of dried fruits: An overview. In Alasalvar C., Shahidi, F. (Eds.), Dried fruits: Phytochemicals and health effects Oxford: Wiley-Blackwell (2013a)1-18

[45] Alasalvar, C., Shahidi, F.: Nutritional composition, phytochemicals, and health benefits of dates. In C. Alasalvar \& F. Shahidi (Edss.), Dried fruits: Phytochemicals and health effect, Oxford:Wiley-Blackwell (2013b) 428-43

[46] Chang, S.K., Alasalvar, C., Shahidi, F.: Review of dried fruits: phytochemicals, antioxidant efficacies, and health benefits. Journal of Functional Foods 21 (2016) 113-132

[47] Garrido, I., Monagas M., Gomez-Cordoves C., Bartolome B.: Polyphenols and antioxidant properties of almonds skins:influence of industrial processing. J Food Sci.73(2)C (2008)106-15

[48] David, C. Nieman et al.: Influence of Pistachios on Performance and Exercise- Induced Inflammation, Oxidative Stress, Immune Dysfunction, and Metabolite Shifts in Cyclists: A Randomized, Crossover Trial. PLOS ONE 9(11) (2014) e113725

[49] Jing, Li., Ji, Wang., Chunlei, Liu., Li, F., Weihong, M.: Protein Hydrolyzates from Changbai Mountain Walnut (Juglans mandshurica Maxim.) Boost Mouse ImmuneSystem and Exhibit Immunoregulatory Activities, Hindawi Evidence-Based Complementary and Alternative Medicine 10 (2018)

[50] WH Foods, 2014: http://www.whfoods.com/genpage.php?tname=foodspice\&amp;dbid=98

[51] Ho, E., Zinc. Linus Pauling Institute. Retrieved fromhttp://lpi.oregonstate.edu/mic/minerals/zinc (2013)

[52] Maixent: Pharmaceutical packaging.Alufoil (2012)12-14

[53] Terrie: Protect Your Health with Immune-Boosting Nutrition. Academy of Nutrition and Dietetics (2017)15-16

[54] Swaminathan, Lucas, Harley, Michael, M.C., Gavilan: Hunger Nielsen shopper trend. (2014)16-19

[55] Fehr, A. R., Perlman, S.: Corona viruses: an overview of their replication andpathogenesis. Methods Mol Biol. 1282, (2015)1-23

[56] Humbert, P., Mikosinki, J., Benchikhi, H., Allaert, F. A.: Efficacy and safety of a gauze pad containing hyaluronic acid in treatment of leg ulcers of venous or mixed origin, controlled trial. Int Wound J. 10(2) (2013) 159-66

[57] Lin, L. T., Hsu, W. C., Lin, C. C, Antiviral natural products and herbal medicines. Journal of traditional and complementary medicine 4(1), (2014) 24-35

[58] Carr, AC., Frei, B.:Toward a new recommended dietary allowance for vitamin C based on antioxidant and health effects in humans. Am J Clin Nutr. 69(6) (1999)1086-1107

[59] Deluca, H.L.R., Cantorna, M.T.: Vitamin D: its role and uses in immunology. FASEB 15 (2001) 25792585

[60] Kuhnlein, H.V.,Receveur, O., Soueida, R., Egeland, G.M.: Arctic indigenous peoples experience the nutrition transition with changing dietary patterns and obesity. J Nutr. 134 (2004)1447-53

[61] Moffatt, M.E.: Current status of nutritional deficiencies in Canadian aboriginal people. Can J Physiol Pharmacol. 73 (1995)754-8

[62] Astley, S.B.: Dietary antioxidants past, present and future. Trends Food Sci Technol.14 (2003)93-8

[63] Jolad, S.D., Lantz, R.C., Solyom, A.M., Chen, G.J., Bates, R.B., Timmermann, B.N.: Fresh organically grown ginger (Zingiber officinale), Composition and effects on LPS-induced PGE2 production. Phytochemistry 65 (2004)1937-54

[64] Jirovetz, L., Buchbauer, G., Stoilova, I., Stoyanova, A., Krastanov, A., Schmidt, E.: Chemical composition and antioxidant properties of clove leaf essential oil. J Agric Food Chem. 54(17) (2006) 6303-6307

[65] Araújo, M. C., Dias, F. L., Takahashi, C. S.: Potentiation by turmeric and curcumin of gamma- radiationinduced chromosome aberrations in Chinese hamster ovary cells. Teratog Carcinog Mutagen (19) (1999) 9-18 
[66] Agbor, G.A., Vinson, J.A., Oben, J.E., et al.: Comparative analysis of the in vitro antioxidant activity of white and black pepper. Nut Res. 26(12) (2006) 659-663

[67] Jayaprakasha, G.K., Rao, L.J.: Chemistry, biogenesis, and biological activities of Cinnamomum zeylanicum. Crit Rev Food Sci Nutr. 51 (2011) 547-62

[68] Anilkumar, K. R., Saritha, V., Khanum, F., Bawa, S. A.: Ameliorative effect of ajwain extract on hexachlorocyclohexane-induced lipid peroxidation in rat liver. Food and Chem. Toxicol. 47 (2009) 279282

[69] New Delhi, India. Government of India, Ministry of Health and Family Welfare, Department of Ayurveda, Yoga \&amp; Naturopathy, Unani, Siddha and Homoeopathy (AYUSH) (2016)

[70] Hebbar, S. S., Harsha, V. H., Shripathi, V., Hegde, G. R.: Ethnomedicine of Dharwad district in Karnataka, India-plants used in oral health care. Journal of Ethnopharmacology 94(2-3) (2004) 261-266.

[71] Chopra, R., Chopra, I.: Glossary of Indian Medicinal Plants. Council of Scientific \&Industrial Research, New Delhi, India (1992)

[72] Vasudevan P., Kashyap S., Sharma S.: Bioactive botanicals from basil (Ocimum sp.) J Sci Ind Res. 58 (1999) 332-8

[73] Mediratta, P.K., Sharma, K.K., Singh, S.: Evaluation of immunomodulatory potential of Ocimum sanctum seed oil and its possible mechanism of action. J Ethnopharmacol. 80 (2002)15-20

[74] Hemalatha, R., Babu, K.N., Karthik M., Ramesh, R., Kumar, B.D., Kumar, P.U.: Immunomodulatory activity and Th1/Th2 cytokine responsticle of Ocimum sanctum in myelosuppressed swiss albino mice. Trends Med Res. 6 (2011) 23-31

[75] Tripathi, A.K., Rajora, V.S., Gupta, D.K., Shukla, S.K.: Immunomodulatory activity of Ocimum sanctum and its influence on cyclophosphamide induced immunosupression. Indian J Anim Sci. 78 (2008) 33-6

[76] Goel, A., Singh, D.K., Kumar, S., Bhatia, A.K.: Immunomodulating property of Ocimum sanctum by regulating the IL-2 production and its mRNA expression using rat splenocytes. Asian Pac J Trop Med. 3 (2010) 8-12

[77] Pavaraj, M., Balasubramanian, V., Baskaran, S., Ramasamy, P.: Development of immunity by extract of medicinal plant Ocimum sanctum on common carp Cyprinus carpio (L.). Res J Immunol. 4 (2011)12-8

[78] Chitra, G., Krishnaveni, N.: Immunostimulatory effect of Ocimum sanctum leaf extract on the Indian major carp, Catla catla. Plant Archives 11 (2011) 213-4

[79] Mondal, S., Varma, S., Bamola, V.D., Naik, S.N., Mirdha, B.R., Padhi, M.M., et al.: Double-blinded randomized controlled trial for immunomodulatory effects of Tulsi (Ocimumsanctum Linn.) leaf extract on healthy volunteers. J Ethnopharmacol. 136 (2011) 452-6

[80] Retrieved from https://www.webmd.com/cold-and-flu/cold-guide/echinacea-common-cold\#1

[81] McKeown, K.A.: A review of the taxonomy of the genus Echinacea. In: Janick J,editor. Perspectives on new crops and new uses. Alexandria, VA: ASHS Press. (1999) 482-98

[82] Manayi, A., Vazirian, M., Saeidnia, S.: Echinacea purpurea: Pharmacology,phytochemistry and analysis methods. Pharmacogn Rev. 9(17) (2015) 63-72

[83] Rajagopal, S., Kumar, R.A., Deevi, D.S., Satyanarayana, C., Rajagopalan, R.: Andrographolide, a potential cancer therapeutic agent isolated from Andrographis paniculata. Journal of Experimental Therapeutics and Oncology 3(3) (2003)147-158

[84] Calabrese, C., Berman, S.H., Babish, J.G., et al.: A phase I trial of andrographolide in HIV positive patients and normal volunteers. Phytotheraphy Research 14(5) (2000) 333-338

[85] Nanduri, S., Nyavanandi, V.K.,Thunuguntla, S. R. et al.: Synthesis and structure-activity relationships of andrographolide analogues as novel cytotoxic agents. Bioorganic \& amp; Medicinal Chemistry Letters 14(18) (2004) 4711-4717

[86] Jayakumar, T., Hsieh, C.Y., Lee, J. J., Sheu, J. R.: Experimental and Clinical Pharmacology of Andrographis paniculata and Its Major Bioactive Phytoconstituent Andrographolide, Evid Based Complement Alternat Med. 2013 (2013)

[87] Del baño, M.J., Lorente, J., Castillo, J., Benavente-Garcia, O., Marín, P., Del Río, J.A., Ortuó, A., Ibarra, I.: Flavoid distribution during the development of leaves flowers, stems and roots of Rosmarinus officinalis postulation of the Biosynthetic pathway. J. Agric. Food Chem. 52 (2004) 4987-4992

[88] Bat-Chen, W., Golan, T., Peri, I., Ludmer, Z., Schwartz, B.: Allicin purified from freshgarlic cloves induces apoptosis in colon cancer cells via Nrf2. Nutrition and Cancer 62 (2010) 947-957

[89] Govardhan Sharma, C.: Ashwagandharishta- Rastantra Sar Evam Sidhyaprayog Sangrah-Krishna-Gopal Ayurveda Bhawan(Dharmarth Trust) Nagpur (1938) 743-744

[90] Samhita, C.: Charaka translation into English: Translator: Shree Gulabkunverba Ayurvedic Society. Jamnagar, India. (1949)

[91] Ferman, J.: Ashwagandha: The Ancient Indian Superherb That Rejuvenates Your Body and Brain From the Inside Out. Retrieved from https://www.consciouslifestylemag.com/ashwagandha-benefits-withania/

[92] De Franceschi, L., Brugnara, C., Beuzard, Y.: Dietary magnesium supplementation ameliorates anemia in a mouse model of beta-thalassemia. Blood 90(3) (1997)1283-90.

[93] BJ, C.: Iron and immunity: immunological consequences of iron deficiency and overload. Journal of Arch Immunol Ther Exp (Warsz). 58(6) (2010) 407-15. 
ICAASET-2021, 20-21 May, 2021, K.R. Mangalam University, Gurugram

International Journal of Technical Research \& Science (Special Issue) ISSN No.:2454-2024 (online)

[94] Beard, J.L.: Iron biology in immune function, muscle metabolism and neuronal functioning. Journal of Nutrition 131(2S-2) (2001) 568S-580S

[95] Kawai, T., Akira, S.: The role of pattern recognition receptors in innate immunity: update on Toll-like receptors. Journal of Nat Immunol. 11(5) (2010) 373-384

[96] Collins, H.L., Kaufmann, S.H., Schaible, U.E.: Iron chelation via deferoxamine exacerbates experimental salmonellosis via inhibition of the nicotinamide adenine dinucleotide phosphate oxidase-dependent respiratory burst. Journal of Nat Immunol. 168(7) (2002) 3458-3463

[97] Prasad, A.S.: Zinc in Human Health: Effect of Zinc on Immune Cells. Journal of Molecular Medicine 14(5-6) (2008) 353-357

[98] Andreini, C., Banci, L., Bertini, I., Rosato, A.: Counting the zinc-proteins encoded in the human genome. J Proteome Res. 5(1) (2006)196-201

[99] Wessels, I., Maywald, M., Rink, L.: Zinc as a Gatekeeper of Immune Function. Nutrients 9(12) (2017) 1286

[100] Prasad, A.S., Miala, A.Jr., Farid, Z., Sandstead, H.H., Schulert, A.R.: Zinc metabolism in patients with the syndrome of iron deficiency anemia, hepatosplenomegaly, dwarfism, and hypogonadism. Journal of $\mathbf{J}$ Lab Clin Med. 61 (1963) 537-549

[101] Vig, M., Kinet, J.P.: Calcium signaling in immune cells. Journal of Nat Immunol. 10(1) (2009) 21-27

[102] Franke K.W. : A New Toxicant Occurring Naturally in Certain Samples of Plant Foodstuffs: I. Results Obtained in Preliminary Feeding Trials: Eight Figures. The Journal of Nutrition 8(5) (1934) 597-608

[103] Behne, D., Wolters, W.: Distribution of selenium and glutathione peroxidase in the rat. Journal of Nutrition 113(2) (1983) 456-461

[104] Bainbridge, D.R.: Use of (75Se)L-Selenomethionine as a label for lymphoid cells. Journal of Immunology 30(1) (1976)135-144

[105] Gromer, S., Eubel, J.K., Lee, B.L., Jacob, J.: Human selenoproteins at a glance. Journal of Cell Mol Life Sci. 62(21) (2005) 2414-2437

[106] Feuerstein, G.: The parth of yoga: An essential guide to its principles and practices. Boston: Shambala (2011)

[107] Desikachar, K., Bragdon, L., Bossart, C.: The yoga of healing: Exploring yoga's holistic model for health and wellbeing. International Journal of Yoga Therapy 15(1) (2005)17-39

[108] Falkenberg, R.I., Eising, C., Peters, M. L.: Yoga and immune system functioning: a systematic review of randomized controlled trials. Journal of J Behav Med. 41(4) (2018) 467-482

[109] Zhu, W.:. Should, and how can, exercise be done during a coronavirus outbreak? Personal interview with Dr. Jeffrey A. Woods. Journal of Sport Health Sci. 9(2) (2020)105-107

[110] Balaji, P.A., Varne, S.R., Ali, S.S.: Physiological effects of yogic practices and transcendental meditation in health and disease. Journal of North Am J Med Sci. 4(10) (2012) 442-448.

[111] Dang K.K., Sahay, B.K.. Yoga and Meditation, Medicine update. The Association of Physicians of India ed MM.Singh. APICON, The Association of Physicians of India conference, New Delhi 9(1) chapters 57 \& 58 (1999) 502- 512

[112] Sahay, B.K., Murthy, K.J.R.: Long term follow up studies on effect of yoga in diabetes. Diab Res Clin Pract. 5(S1) (1988) S655

[113] Chandratreya, $\quad$ S. (2012). $\quad$ Diabetes \& $\quad$ Yoga. $\quad$ Retrieved from http://www.yogapoint.com/therapy/diabetes_yoga.htm.

[114] Delmonte, M.M. (1985). Biochemical indices associated with meditation practice: A literature review. Journal of Neurosci Biobehav Rev. 9(4), 557-61.

[115] Tulpul, T.H., Shah, H.M., Shah, S.J., \& Haveliwala, H.K. (1971). Yogic exercises in the management of ischaemic heart disease. Journal of Indian Heart. 23(4), 259-64.

[116] Jerath, R.J., Edry, V.A., Barnes, V.A., \& Jerath, V. (2006). Physiology of long pranayamic breathing: Neural respiratory elements may provide a mechanism that explains how slow breathing shifts the autonomic nervous system. Journal of Med Hypotheses. 67(3), 566-71.

[117] Luders, E., Toga, A.W., Lepore, N., \& Gaser, C. (2009). The underlying anatomical correlates of longterm meditation: Larger hippocampal and frontal volumes of gray matter. Journal of Neuroimage. 45(3), $672-678$.

[118] Van Leeuwen, S., Singer, W., \& Melloni, L. (2012). Meditation Increases the Depth of Information Processing and Improves the Allocation of Attention in Space. Journal of Front Hum Neurosci. 6, 133.

[119] Gopal, A., Mondal, S., Gandhi, A., Arora, S., Bhattacharjee, J. (2011). Effect of integrated yoga practices on immune responses in examination stress - A preliminary study. Journal of Int J Yoga. 4(1), 26-32.

[120] Visweswaraiah, N.K., Telles, S.: Randomized trial of yoga as a complementary therapy for pulmonary tuberculosis. Journal of Respirology 9(1) (2004) 96-101

[121] Samuel, S.: Our calm is contagious : How to use mindfulness in a pandemic. Retrieved fromhttps://www.vox.com/future-perfect/2020/3/18/21181644/coronavirus-covid-19-mindfulnessmeditation-anxiety, (2020)

[122] Pakhare, N.: How Yoga and Ayurveda might help prevent being infected by Coronavirus. Retrieved from https://www.esamskriti.com/e/Yoga/Therapy/How-Yoga-and-Ayurveda-might-help-prevent-beinginfected-baaay-Coronavirus-1.aspx(2020, March 11)

[123] https://www.health.gov.au/health-topics/novel-coronavirus-2019-ncov 
ICAASET-2021, 20-21 May, 2021, K.R. Mangalam University, Gurugram

International Journal of Technical Research \& Science (Special Issue) ISSN No.:2454-2024 (online)

[124] Gallagher, J.: Coronavirus: Are women and children less affected? Retrieved from https://www.bbc.com/news/health-51774777, (2020, March 8)

[125] Gallagher, J.: Coronavirus: What it does to the body. Retrieved from https://www.bbc.com/news/health51214864 (2020, March 14)

[126] Coronavirus pandemic: Which politicians and celebs are affected? Retrieved from https://www.aljazeera.com/news/2020/03/coronavirus-pandemic-politicians-celebs-affected200315165416470.html

[127] Page, J., Fan, W., \& Khan, N.: How It All Started: China’s Early Coronavirus Missteps. Retrieved from https://www.wsj.com/articles/how-it-all-started-chinas-early-coronavirus-missteps-11583508932 (2020, March 6)

[128] Coronavirus (COVID-19) health alert. Retrieved from https://www.health.gov.au/health-topics/novelcoronavirus-2019-ncov

[129] Eichenseher, T.: Stressed About Coronavirus? Here's How Yoga Can Help. Retrieved from https://www.yogajournal.com/lifestyle/ayurveda-and-yoga-for-flu-and-coronavirus (2020, March 2)

[130] Kahn M.D., J. S., McIntosh, Kenneth, M.D.: History and Recent Advances in Coronavirus Discovery. The Pediatric Infectious Disease Journal 24(11) (2005) S223-S227. 